in your chapter about how you can individually and collectively promote the benefits of librarianship.

If we all do our share of lively recruiting, the next comment we should hear is, "Gosh, I didn't know librarians could do all that!"

$E d$. note: This article first appeared in the Eastem NewYork/ACRLChapter Newsletter, Fall 1991, and is reprinted with permission.

\title{
Literacy and social issues topics at Society of American Archivists meeting
}

Nearly 1,300 archivists, manuscript curators, records managers, and preservation specialists convened in Philadelphia September 23-29 for the 55th Annual Meeting of the Society of American Archivists (SAA). This record number of participants for an SAA meeting enjoyed a multifarious program of 87 formal sessions and workshops, plus a plethora of committee, round table, and section meetings. The program was complemented by a wide variety of tours of Philadelphia's sights and institutions, and rounded out with a large number of social events, all orchestrated by the Host Committee.

SAA president Trudy H. Peterson, of the National Archives and Records Administration, challenged the membership with disturbing observations in her Presidential Address, "Reading, 'Riting and 'Rithmetic: Speculations on Change in the Research Process." Beginning with a brief historical overview of the development of widespread literacy, Peterson observed that the ability to read and write is a comparatively recent social phenomena, one that may well have peaked. She went on to speculate on the implications that declining literacy may have on public cultural institutions like archives. Noting that the need for information will not decline with the public's ability to assimilate it directly from texts, Peterson posited a growing intensity in the services that archivists will be called on to provide, and a major shift in the way archival materials are organized and controlled. Her sobering reflections are directly relevant to research libraries. Many of the program sessions were also of direct relevance to the interests of ACRL members, perhaps witnessing the continuing convergence of the archival and library professions. Statewide preservation planning, the ALA Standards for Accreditation, geographic information systems (GIS), administering audio recordings, user studies, fakes and forgeries, friends groups, women in management, copyright, trends in research methodologies, information policy development, and preservation education were but a few of the topics to which program sessions were devoted. A number of the SAA sessions might easily appear on an ACRL meeting program, including those on services for genealogists, local and regional history manuscripts, mass deacidification, and the impact of technology on reference services.

Many of the business meetings of the committees and round tables were also marked by concerns that are of interest tolibrarians. A few examples: the SAA Task Force on Library Archives is attempting to devise strategies for increasing the awareness among librarians that the records of their institutions are important cultural materials, and that the disposition of these records is probably governed by state records statutes; the NOTIS Users Round Table and the RLIN Users Round Table discussed archi$\mathrm{val}$ aspects of the respective systems that librarians may view as their own; and the Archival Educators Round Table reviewed a number of developments in library education that have impact on still-developing archival education.

The SAA business meeting also touched on a number of themes that ACRL members might find familiar. One of these revolved around a set of guidelines for access to primary source materials drafted by ACRL's Rare Books and Manuscripts Section, which SAA has been asked to adopt jointly. The issue with the most striking parallel to ACRL, however, is the question of taking political and social factors into account in selecting meeting sites. Arising originally out of the invitation to hold the 1996 Annual Meeting in Salt Lake City, which has been opposed by some members of SAA due to Utah's stringent anti-abortion law, the issue has broadened to include other social and political factors. SAA's action in this matter is still pending; a decision regarding the 1996 meeting, and the process for selecting future meeting sites, is expected at the January meeting of Council. In short, the SAA meeting was chock full of interesting and informative events useful to college and research librarians. ACRL members should consider keeping an eye on SAA Annual Meetings in the future, and take advantage of the opportunity to attend when convenient. Future meetings are planned for Montreal, September 14-18, 1992, and New Orleans, September 2-5, 1993. For more information contact the SAA, 600 S. Federal, Suite 504, Chicago, IL 60605; (312) 922-0140.-Robert S. Martin, Assistant Dean for Special Collections, LSU Libraries, Louisiana State University 